Cronfa - Swansea University Open Access Repository

This is an author produced version of a paper published in :

Surgery

Cronfa URL for this paper:

http://cronfa.swan.ac.uk/Record/cronfa27414

\title{
Paper:
}

Azzopardi, E., Lloyd, C., Rodrigues Teixeira, S., Conlan, R. \& Whitaker, I. (2016). Clinical applications of amylase: Novel perspectives. Surgery

http://dx.doi.org/10.1016/j.surg.2016.01.005

This article is brought to you by Swansea University. Any person downloading material is agreeing to abide by the terms of the repository licence. Authors are personally responsible for adhering to publisher restrictions or conditions. When uploading content they are required to comply with their publisher agreement and the SHERPA RoMEO database to judge whether or not it is copyright safe to add this version of the paper to this repository. http://www.swansea.ac.uk/iss/researchsupport/cronfa-support/ 


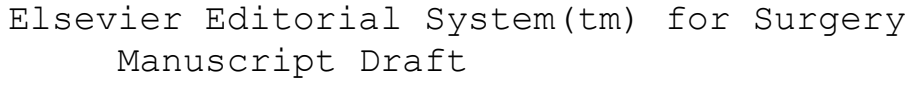

Manuscript Number: 20150922R2

Title: Clinical Applications of Amylase: Novel Perspectives

Article Type: Clinical Review

Section/Category: Basic Research

Keywords: amylase; nanomedicine; pancreatitis; surgical site infection; wound healing; theranostics

Corresponding Author: Dr.Med. Ernest A. Azzopardi, MRCSEd MSc Surg MD PhD Corresponding Author's Institution: 1. Reconstructive and Regenerative MedicinedIL Group

First Author: Ernest A. Azzopardi, MRCSEd MSc Surg MD PhD

Order of Authors: Ernest A. Azzopardi, MRCSEd MSC Surg MD PhD; Catherine Lloyd, B Sci; Rosa S Rodriguez Texiera, PhD; Robert Steven Conlan , PhD FRSB; Iain S Whitaker, MA(Cantab) FRCS(Plast) PhD

Manuscript Region of Origin: UNITED KINGDOM

Abstract: Please refer to the manuscript text, where the abstract is located. 
Subject: RE: Author query SURG 20150922R2

From: Kerri Crowley (surgery@stellarmed.com)

To: $\quad$ ernest_azzopardi@yahoo.co.uk;

Date: Wednesday, 20 January 2016, 15:02

Dear Dr. Azzopardi,

Thank you for your email, I just received notice that your manuscript was accepted for publication in SURGERY, congratulations. However, before I can proceed I need a 2 sentence summary of your article for the Table of Contents. Please send it to me and I can proceed with your article, thank you!

Kind Regards,

Kerri Crowley

Managing Editor

Surgery

p: 508-732-6767, ext. 10

f: $508-732-6766$

-----Original Message------

From: ees.surg.437e.36c0c4.1a668e18@eesmail.elsevier.com

[mailto:ees.surg.437e.36c0c4.1a668e18@eesmail.elsevier.com] On Behalf Of Ernest Azzopardi Sent: Wednesday, January 20, 2016 5:38 AM

To: surgery@stellarmed.com

Subject: Author query SURG 20150922R2

Please enter your name, e-mail address and query below, then click 'Preview and Send'.

Name:ernest azzopardi

E-mail address:ernest_azzopardi@yahoo.co.uk

Query:

Dear Managing Editor,

Thank you for your help in a recent telephone conversation with regard to this manuscript. I am wondering if there is anything further required from our end. Many thanks in anticipation.

Yours faithfully

E. Azzopardi

Please do not modify the text below this line. 
From Corresponding author: Dr.Med. Ernest A. Azzopardi

Journal title: Surgery

Article title: Clinical Applications of Amylase: Novel Perspectives

Manuscript number: 20150922R2 


\section{Clinical Applications of Amylase: Novel Perspectives}

Running Title: Amylase, novel perspectives

Authors:

Ernest Azzopardi ${ }^{* 1-4}$

Catherine Lloyd ${ }^{* 12}$

Sophia Rodriguez Texeira ${ }^{2}$

R. Steven Conlan ${ }^{* * 2,4}$

lain S Whitaker ${ }^{* *} 1,3,4$

* Joint first authorship

** Joint Senior Authorship

1. Reconstructive Surgery and Regenerative Medicine Group, Swansea University, UK

2. Centre for Nanohealth, Swansea University, UK

3. The Welsh Centre for Burns and Plastic Surgery

4. Swansea University Medical School, Swansea UK

Corresponding author and institution: Ernest Azzopardi Institute for Life Sciences, Swansea University Medical School, Swansea University, UK. e.a.p.azzopardi@swansea.ac.uk;

Email addresses: Catherine Lloyd Cath.lloyd@live.me; Sofia Rodrigues-Texeira: r.rodriguesteixeira@swansea.ac.uk ; R. Steven Conlan r.s.conlan@swansea.ac.uk lain Whitaker: iainwhitaker@fastmail.fm

Work on this manuscript has been funded by a small research grant from the Royal College of Surgeons in Edinburgh; Catherine Lloyd is funded on a full Master of Science by Research by the KESS scholarship scheme (Wales, UK).

Article type: Review article

Text: $\quad 3000$ words

Abstract: $\quad 218$ words

Figures: $\quad 2$

Tables: $\quad 3$ 


\begin{abstract}
Amylase was the first enzyme to be characterised, and for the past 200 years, its clinical role was restricted to a diagnostic aid. Recent interface research has led to a substantial expansion of its role into novel, viable diagnostic and therapeutic applications to cancer, infection, and wound healing. This review provides a concise "state of the art" overview of the genetics, structure, distribution, and localisation of amylase in humans. To the four classical hyperamylasemia patterns (pancreatic, salivary, macroamylasemia, and combinations) a fifth, the localised targeting of amylase to specific foci of inflammation is proposed. The implications are directed at novel therapeutic and diagnostic clinical applications of amylase such as the novel therapeutic drug classes capable of targeted delivery and "smart release" in areas of clinical need. Future directions of research in areas of high clinical benefit are reported.
\end{abstract}




\section{Introduction}

Infection, cancer impaired wound healing continue to present formidable challenges to the current practice of surgery. ${ }^{1-4}$ Combined, these represent the main cause of mortality, morbidity and recurrent health expenditure worldwide. ${ }^{5}$ Additionally, the disproportionate increase in multidrug resistant infection against the decline in development of novel antibiotics has been recognised as a global threat in many areas of medicine and surgery. ${ }^{6-8}$ Therefore, novel developments with the potential to improve diagnostics and therapeutics across all three fields are highly sought after.

Amylase was the first enzyme to be discovered and isolated by Payen in $1833 .{ }^{9,}{ }^{10}$ Over the last 190 years, its use in the diagnosis of pancreatic and associated diseases has been well-established. ${ }^{11}$ The last 20 years have witnessed intensive research into expanding the clinical applications of this venerable enzyme with high relevance to surgical management, including the treatment of surgical infection, solid cancer, and wound management. This study provides a concise "state of the art" overview of advances in basic science concerning amylase structure, function, and bio-distribution, leading into clinically relevant diagnostic and therapeutic applications that have reached clinical practice or advanced stages of development. The review draws on advances at the interface of surgery, diagnostics, synthetic chemistry, and nanomedicine to indicate clinically valid directions for future research.

\section{Methods}

A first generation literature search was performed using the MeSH ${ }^{12}$ search string "Amylase AND (diagnost* OR therapeut\$)" on the OVID-SP and PUBMED platforms. 1755 studies were retrieved and screened for relevance. A second generation search was then performed by forward and backward referencing on Web of Knowledge ${ }^{\mathrm{TM}}$ and manual indexing. Only articles with full text available in English were included. 


\section{Literature Review}

\subsection{Amylase Enzyme Classification}

Amylases are part of a large group of glycosyl hydrolase enzymes that catalyse the breakdown of complex carbohydrates. ${ }^{13,14}$ Fifty seven families of glycosyl hydrolases have been classified based on their function and specificity ${ }^{15}$ (Table 1$)$. Of the three main classes of amylase enzymes $(\alpha, \beta$ and $\gamma)$, $\alpha$ amylase is found in animals, plants, fungi, and bacteria, $\beta$ amylase is found in plant seeds, bacteria and fungi and $\gamma$ amylase is found in yeast and fungi. The main function of all of the amylases is to degrade starch and sugars. However, there is a difference in their structure and mode of action. $\alpha$-amylase cleaves randomly along the starch chain and because of this non-specificity, digestion is more rapid than other amylases. $^{16}$

\subsection{Human $\alpha$-amylase: genetics and function-structure considerations}

Salivary $\alpha$-amylase is expressed in salivary, mammary, and lacrimal glands, while the pancreatic isoform is only expressed in the pancreas. ${ }^{17}$ Pancreatic $\alpha$-amylase constitutes $5-6 \%$ of the total protein present in pancreatic secretions, and unlike many other pancreatic enzymes, it has no inactive precursor. ${ }^{18}$ Gene structure suggests that the human salivary amylase gene has evolved from a pre-existing pancreatic amylase gene. Figure 1 reports the relationship between structure, function, and genetics of this enzyme family.

\subsection{Mode of action, cofactors, and clinically relevant substrates}

Current assays only measure activity, and therefore the mode of action, environmental conditions, presence of cofactors, and substrate nature merit consideration. Figure 2 illustrates that the mode of action of $\alpha$-amylase is a double displacement mechanism. Human $\alpha$-amylase requires two essential 
cofactors for its activity: chloride and calcium ions. ${ }^{19}$ The $\alpha$-amylases are calcium metalloenzymes and are unable to function in the absence of calcium. ${ }^{19}$ The calcium ion is coordinated between 8 ligands from the main amino acid chain, side chains, and three water molecules while the chloride ion binds closely to the active site and is considered to act as an allosteric activator. Several medical devices chelate calcium, possibly affecting amylase activity, for instance alginate dressings. ${ }^{20,}{ }^{21}$ Several amylase inhibitors have been identified and used clinically in the treatment of human disease (Section 3.7). Whereas the physiologic $\mathrm{pH}$ range of blood is $7.35-7.45$, the optimum $\mathrm{pH}$ for amylase activity is 6.7 to 7.0, which would be expected in pathophysiologic states such as infection and possibly solid tumors. ${ }^{22}$ Localised amylase concentrations are increasingly important in the development of amylase-based therapeutics (section 3.5). Such devices and medical dressings may also adversely affect the amylase assays in current use because they are activity, not concentration based (section 3.5).

\subsection{Distribution in Pathophysiologic States}

The classic diagnostic use of $\alpha$-amylase presupposes that the plasma concentration of $\alpha$-amylase reflects the pathophysiologic processes in the source organ, and increases in $\alpha$-amylase activity in human serum has traditionally formed the basis of its clinical applicability. Four patterns of generalised hyperamylasemia have been recognized: pancreatic, salivary, macroamylasemia, and combinations thereof. ${ }^{19}$ Pancreatic and salivary disease are described extensively elsewhere. ${ }^{23}$ Macroamylasemia is the increase of serum $\alpha$-amylase due to a macromolecular complex between amylase and immunoglobulins which imparts increased size and molecular weight. This benign biochemical aberration only affects approximately $0.4 \%$ of the general population. ${ }^{24-26}$ but can be a source of diagnostic confusion. ${ }^{27}$ Table 2 provides examples of clinical conditions associated with hyperamylasaemia. Additionally it is proposed that amylase can sequestrate locally at operative sites of enhanced vascular permeability or bacterial infection. 


\subsubsection{The Enhanced Permeability and Retention (EPR) Phenomenon}

The EPR effect is mediated by the enhanced vascular permeability and distorted/dysfunctional lymphatic drainage of macromolecules at sites of localized inflammation. ${ }^{28}$ Large molecules such as amylase may therefore be retained in areas of enhanced vascular permeability and distorted drainage such as infection. It has been recently proposed that the EPR effect is mediated by Bradykinin, resulting in localised hyperpermeability of the microvasculature. Based on this notion, novel bio responsive antibiotics have been described recently. 29, 30 Evidence of localisation of amylase to surgical site infection has been claimed from a consecutive series of patients $(n=6)$ with infected burn wounds, ${ }^{31,32}$ but it is known that amylase is present in sweat. Interestingly, histamine has also been reported recently to stimulate secretion of pancreatic $\alpha$-amylase into the gastrointestinal tract and increase vascular permeability. ${ }^{33-35}$

\subsubsection{Bacterial amylase}

Bacterial amylase is essential to the Bacillus and Clostridium genus. ${ }^{36-40}$ Such bacteria cannot absorb starches and therefore, $\alpha$-amylase is constitutively secreted, digesting glucose which can then be absorbed. ${ }^{41}$ Interestingly, organisms in this genus are capable of prolific amylase secretion, and may consequently increase amylase levels around the infected site by several orders of magnitude. ${ }^{41-47}$ Several organisms in these genuses are responsible for life-threatening human infection, often requiring urgent treatment including C. perfringens (gas gangrene), ${ }^{48}$ C. tetanii (tetanus), ${ }^{49}$ C. difficile (hospital acquired pseudomembranous colitis), ${ }^{50,51}$ and B. cereus (food poisoning). Several Bacillus species are exploited in the alimentary biotechnology industry for their prolific amylase production. ${ }^{52,53}$ Harnessing this phenomenon for clinical diagnostic and / or therapeutic applications, however, has not yet been reported. Additionally, Aeromonas hydrophila, a Gram negative pathogen, constitutively expresses 
Dextrin and dextran are mentioned here as two salient examples. Dextrin is a $\alpha-1,4$ poly (D-glucose) polymer obtained from hydrolysis of starch. Dextrins are largely linear polymers with limited $(<5 \%)$ branching in the $\alpha-1,6$ position and have an established safety profile. ${ }^{63,64}$ Dextrin's versatility to several clinical applications has been well-established. Dextrin is used as a supplement for renal and hepatic failure ${ }^{65}$ as a carrier for intraperitoneal 5-fluorouracil, ${ }^{66,67}$ and as a component of peritoneal dialysis solutions. ${ }^{68}$ In contrast, dextran is a complex, branched glucose polymer which consists of both $\alpha-1,6$ glycosidic linkages and branches at $\alpha-1,3$ linkages. ${ }^{69}$ Dextran is used medicinally as an antithrombotic (antiplatelet) to decrease blood viscosity and as a volume expander in hypovolaemia. ${ }^{70}$ Amylase is the enzyme which provides a predictable, safe degradation of these polymers in the bloodstream, eventually resulting in hydrolysis to simple sugars that can be fully metabolised. In this regard, $\alpha$ amylase triggers hydrolysis of $\alpha-1,4$ glycosidic linkages forming maltose and iso-maltose which are metabolised subsequently to glucose by tissue maltases, and/or excreted into urine. ${ }^{71-73}$ The importance of amylase in this context is often overlooked. Consequently, the effect of co-incidental disease that affects amylase levels, which may dictate the duration of the intended therapeutic effect, is often overlooked (Table 2).

An extra level of complexity can be achieved if these polymers are combined chemically to bioactive, conventional molecules of interest. In fact amylase and its associated polymer substrates have been found to be of considerable interest within the field of polymer therapeutics and specifically the science of conjugating of large, water soluble polymers to bioactive molecules of interest. ${ }^{74,75}$. Coupling a conventional medicinal to a polymer achieves macromolecular status with distinct therapeutic advantages. ${ }^{76-78}$ Polymer therapeutics has yielded some of the major pharmaceutical "block busters" of the past 10 years. $^{74}$ 
Conjugation to a polymer "shields" the body from potential adverse effects of a payload, as well as the payload itself from being degraded, immunologically attacked, or cleared by the kidneys. ${ }^{79}$ Additionally, however, use of a biodegradable polymer with the appropriate enzyme would result in biodegradation and release of the active payload. In this strategy, the biodegradable polymer shields the payload while in transit. Macromolecular status imparts passive targeting of the drug through the EPR effect ${ }^{31,77,80,81}$ allowing accumulation at a site of inflammation. The target enzyme present therein will degrade the polymer releasing the active compound. This approach is termed the Polymer Mask Unmask Protein Principle (PUMPT). ${ }^{82}$

The rate of degradation of this polymer conjugated to a drug of choice can be predicted in vitro and ex vivo by custom-engineering the chain length of the polymer and the degree of pendant groups. ${ }^{76}$ Amylase is an endogenously produced enzyme with multiple polymer substrates that happen to be already licensed for human use. PUMPT was in fact described using amylase and succinoylated dextrin as a proof of principle. ${ }^{81}$ The PUMPT approach has been described for several clinical applications.

Hardwicke et al. used the biodegradable polysaccharide dextrin and a recombinant human epidermal growth factor (rhEGF) as a first in class proof of concept based on the premise that the conjugate would localise to the wound due to the EPR effect. ${ }^{83}$ In 2014, a prototype dextrin-colistin conjugate was customised by polymer modification and binding chemistry to afford selective, controlled release at an infected site was reported. ${ }^{84,85}$ These studies employed the biodegradable, naturally-occurring polymer, dextrin, and different bioactive molecules. ${ }^{82,84,86,87}$

While the EPR effect has been demonstrated to be highly successful in pre-clinical species it has been less successful clinically; therefore, additional levels of complexity to augment targeting have been 
described. One strategy is to add an antibody binding. Tilmanocept is one such example. Tilmanocept is a recently described, mannosylated, dextran-based polymer therapeutic for sentinel lymph node imaging which may offer an innovative solution for patients with melanoma and breast cancer. It has been FDA approved and has not been associated to any of adverse effects. Tilmanocept binds tightly to CD206 mannose receptors on the surface of reticuloendothelial cells resident in lymph nodes for up to $30 \mathrm{~h}^{88}$ In two rigorously conducted phase III trials, Tilmanocept identified correctly a significant proportion (an additional 20\%) of melanoma-positive sentinel nodes that were not detected by blue dye. ${ }^{89}$ Complexity can also be achieved by loading many biological payloads onto a polyfunctional polymer, ${ }^{90}$ such as hydroxyethyl starch conjugation to hemoglobin. ${ }^{91}$ of note, hydroxyethyl starch is a substrate of amylase, and was, until recently, used as a volume expander and carried an increased risk of renal dysfunction and mortality over a 90-day follow-up in patients who received HES compared with crystalloids. ${ }^{92}$ Increased mortality in patients with sepsis was also observed prompting their UK-wide recall. ${ }^{92,}{ }^{93}$ It is likely, however, that these adverse effects would not be associated to the quantities administered for drug delivery, which are minute compared to those required for plasma volume expansion.

The efficacy of such targeting techniques does, however, depend on the underlying principles being widespread phenomena, with sufficient magnitude of effect to allow clinical harnessing. ${ }^{81,94}$. Several studies have focussed on producing novel bioresponsive classes of drugs based on polymer substrates of amylase, but no studies have proven conclusively that amylase actually localises at the site of interest. Application of the same technology to areas where first generation (non-biodegradable) polymer therapeutics have already reached the clinic may have wide-reaching implications for other aspects of surgery, including rheumatoid arthritis, sentinel lymph node identification, and breast cancer. ${ }^{75,78}$ 


\subsubsection{Other clinical therapeutic uses of amylases in surgery}

$\alpha$-amylase is a component in several pharmaceutical enzyme replacement preparations, used to treat pancreatic insufficiency. For instance, due to the absence of the cystic fibrosis trans-membrane regulator (CTFR), the secretion of $\alpha$-amylase is obstructed..$^{95}$ This means patients with cystic fibrosis can be treated with enzyme replacement therapies to prevent malnutrition. ${ }^{96}$ Conversely, $\alpha$-amylase inhibitors have been licensed for the treatment of type 2 diabetes. Acarbose, one such example, is a pseudotetrasaccharide from Actinoplanes spp. which works by binding to the active subsites -3 through to $+2 .{ }^{97,} 98$ Similarly, phaseolamin has been marketed as an enteric amylase inhibitor adjunct to weight loss and is available as an over the counter drug. De Gouveia et al. found that patients treated with phaseolamin did not have any decrease in body weight, but this study was conducted for only 20 days and therefore, follow-up bias could have affected the conclusions of this study. ${ }^{99}$ The use of phaseolamine as an antihyperglycemic is contended. Oliveira et al. found that phaseolamin can be used to control diabetes due to its anti-hyperglycemic effect. ${ }^{100}$ Another study did not find any effect on the glycemic state, although this could be due to the low dose used in the latter study. ${ }^{101}$ Interestingly, the product of amylase activity (glucose) has been shown to inhibit effectively the production of the main toxins responsible for the onset and progression of gas gangrene, lending some credence to claims of antibacterial efficacy of sugar based wound dressings such as Manuka Hone. ${ }^{102}$

\subsubsection{Clinical Diagnostics}

Hitherto, the principal use of $\alpha$-amylase remains in clinical diagnostics. The normal range of human serum $\alpha$-amylase activity is $23-85 \mathrm{IU} / \mathrm{L}$, however there is substantial inter-laboratory and inter-assay variation. ${ }^{86}$ Pancreatic $\alpha$-amylase is produced exclusively by the pancreas which increases its specificity for the diagnosis of pancreatic diseases. Furthermore, detecting the activity of the pancreatic isoform 
compared to the total amylase, increases the sensitivity, therefore differentiating between the two isoforms is important clinically. ${ }^{103,104}$ Various methods to accomplish this differentiation have been described previously in literature, including enzyme-immunoassays and partial inhibition of salivary amylase by various different inhibitors. ${ }^{104}$ Widespread clinical adoption of classic diagnostic and, more recent therapeutic and combined approaches using $\alpha$-amylase are dependent on rapid, cost-effective, and real-time quantification of $\alpha$-amylase activity. A detailed description of state of the art sensors under development or fully developed is provided in the supplementary material (online only). The methods of detection either depend on product formation or substrate degradation or antibody binding. Total $\alpha$-amylase is used as an indication of pancreatic or salivary disease.

The p-nitrophenol assay is directly proportional to $\alpha$-amylase activity and is measured photometrically. The range of detection is 3-1500 IU/L. This assay is used widely in the National Health Service (in the United Kingdom), but it does not distinguish bacterial from human amylase. ${ }^{105}$ In contrast, antibody assays employ a human anti- $\alpha$-amylase antibody as it will eliminate any false positives due to bacterial secretion of amylase, while also being sub-type specific. ${ }^{106}$ Commercially available assays all rely on measuring activity of $\alpha$-amylase, while an antibody approach would quantify concentration of $\alpha$-amylase (as opposed to amylase activity) with a high degree of sensitivity and specificity in control and patient samples. Aluoch et al. designed a novel amperometric biosensor using a salivary anti $\alpha$-amylase antibody which is monitored by an electroactive indicator. This indicator is oxidized or reduced causing current change which gives analytic information on the concentration of amylase. Its limit of detection is 1.57 $\mathrm{pg} / \mathrm{mL}$ which is more sensitive than enzyme-linked immunosorbent assay (ELISA, $10 \mathrm{ng} / \mathrm{mL}$ ). ${ }^{106}$ Although this study describes a simple design, silver precipitation can be a concern because it would lead to insensitivity, possibly limiting this approach to single use, and thereby markedly increasing cost. An experimental "online" in vivo sensor reported by Wu et al. uses starch immobilized on a magneto-elastic 
sensor. In the presence of amylase, there is a decrease in mass loading resulting in an increase in resonance frequency; the device suffers currently from lack of sensitivity. ${ }^{107}$ Nonetheless, this study highlights the potential of rapid, "online" bedside amylase detection methods and offers substantial improvement including cost-effectiveness, and real time measurement. Wang et al. developed a protocol which uses a portable device to measure $\alpha$-amylase concentration. The feasibility of point-of care monitors has been well-established in other clinical conditions such as diabetes. ${ }^{108}$ The methodology of Wu et al. however, requires the sample to be incubated for 15 minutes at $37^{\circ} \mathrm{C}$ for the reaction to occur, which limits the applicability of this method at the point of care, because the sample has to be processed using laboratory equipment before using the sensor. Given the direction of research into amylase as a trigger for several personalisable and therapeutics such as infection, cancer and wound healing, the literature reviewed in this section suggests that miniaturised, cost-effective, personal point-of-care biosensors for $\alpha$-amylase would have potential advantages over current diagnostic approaches. By being able to record amylase activity at a personal, point of care level, such devices may increase the scope of amylase-based therapeutics, expand both diagnostic and therapeutic use into personalised medicine.

\section{Conclusion}

Novel amylase-based therapeutics and diagnostics have experienced a period of intensive research, resulting in novel technologies with substantial clinical potential. Clinically relevant classifications of hyperamylasemia presented in this study may help to direct the surgeon during the "surgical sieve" diagnostic process. Proof-of-concept for the EPR and the PUMPT phenomena may provide novel and bioresponsive "smart" approaches to the management of common surgical disease. These advances are based on interface research linking demand (clinical) to supply (basic sciences), providing novel and exciting solutions to surgical problems of global health concern, and it is, therefore, important for the practicing surgeon to be aware of progress in this field. The advent of portable point-of-care, amylase 
sensing devices may facilitate surgical decision making and applicability of amylase-based polymer therapeutics. Further availability of ex vivo and clinical data to support the use of amylase-based therapeutics would support allow clinical harnessing, and stimulate further development of novel, effective drugs based on such principles.

\section{Abbreviations:}

PUMPT Polymer Mask Unmask Protein Therapy Principle. CAZy = carbohydrate-active enzymes; EPR: Enhanced permeability and retention; PUMPT = polymer mask-unmask protein therapy; CFTR $=$ Cystic Fibrosis Transmembrane Regulator, HIV = Human Immunodeficiency Virus, MetS = Metabolic syndrome; $\mathrm{AMP}=$ Amperometric, $\mathrm{EIS}=$ Electrochemical Impedance Spectroscopy, FAU $=$ Fungal Amylase Unit, FIA $=$ Flow Injection Analysis, $\mathrm{KNU}=$ kilo Novo unit, $\mathrm{LOD}=$ Limit of Detection, $\mathrm{LR}=$ Linear Range, nkat $=$ nanokatals.

\section{Competing interests:}

The authors declare no conflict of interest.

\section{Funding:}

This study was funded by a small research grant from the Royal College of Surgeons in Edinburgh, UK to Ernest Azzopardi. Catherine Lloyd is supported by a Knowledge Economy Skills (KESS) Scholarship (Welsh Assembly Government).

\section{Acknowledgements:}

The authors would like to acknowledge the input of Drs Rachel Still and Dr Jenna Walters Biochemistry, (ABM ULHB NHS Trust) in providing guidance regarding current clinical diagnostic assays for amylase; and help with student supervision. 


\section{Figure Legend}

Figure 1: Systematic representation of the structure of human $\alpha$-amylase (a) Amino acid sequence of human $\alpha$-amylase indicating the binding sites for calcium (orange arrows), chloride (black arrows) and $\mathrm{N}$ glycosylation sites (blue arrows) (b) Active site is a V-shaped cleft subdivided into different sub-sites, glycone, individual sugar residues in a oligosaccharide chain $(-4,-3,-2$ and -1$)$ and aglycone, individual sugar residues after hydrolysis of glycosidic bond $(+1,+2$ and +3$)$. Each sub-site interacts with a monosaccharide, and cleavage occurs between +1 and -1 , shown in the figure by the orange line.

Figure 2: Systematic representation for the hydrolysis of glycosidic linkages by amylase. (a) The first displacement mechanism. The acid group of $\alpha$-amylase reacts with the glyosidic oxygen to form an oxcarbenium ion-like transition state. This goes through nucleophilic attach by the acid of $\alpha$-amylase to give a $\beta$-glycosyl enzyme intermediate. (b) The $\beta$-glycosyl enzyme intermediate reacts with activated $\mathrm{H}_{2} \mathrm{O}$ which forms an oxcarbenium ion-like transition state. The acid group of $\alpha$-amylase is then reprotonated. Most forms of $\alpha$-amylase are endo-enzymes, acting on substrate bonds within the carbohydrate chains, rather than those at the terminal ends. In contrast, maltogenic amylase is an exoenzyme subclass which hydrolyses terminal end residues which lead to them being re-classified as maltogenic amylases. 
(a) Scale from 0 amino acids to 500

(b)

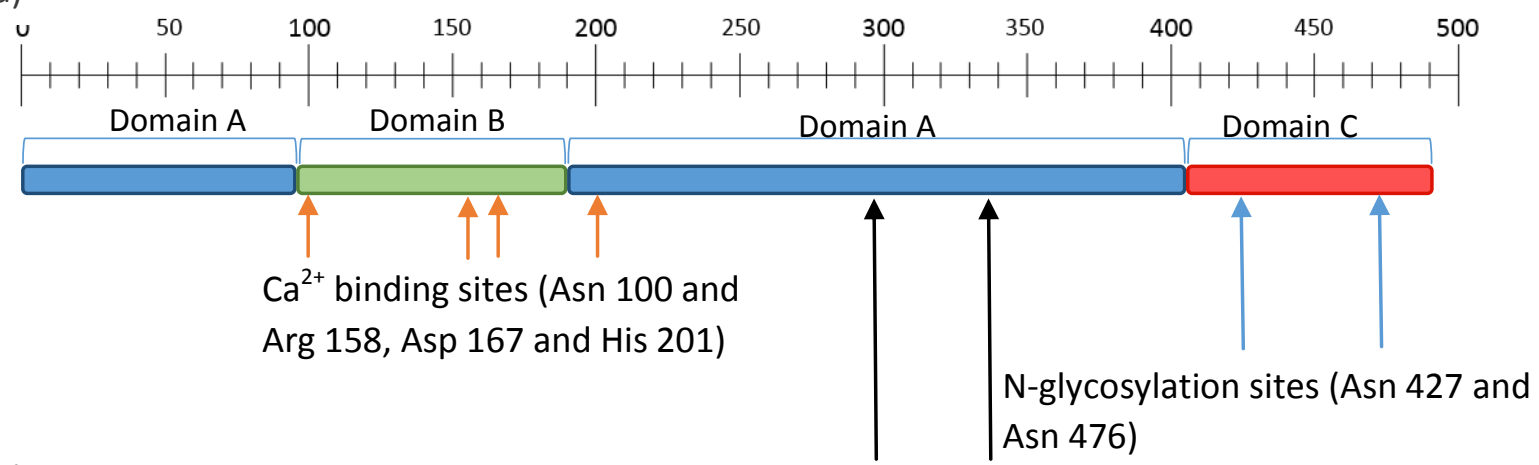

$\mathrm{Cl}^{-}$binding sites (Asn 298 and Arg 337)

(c)

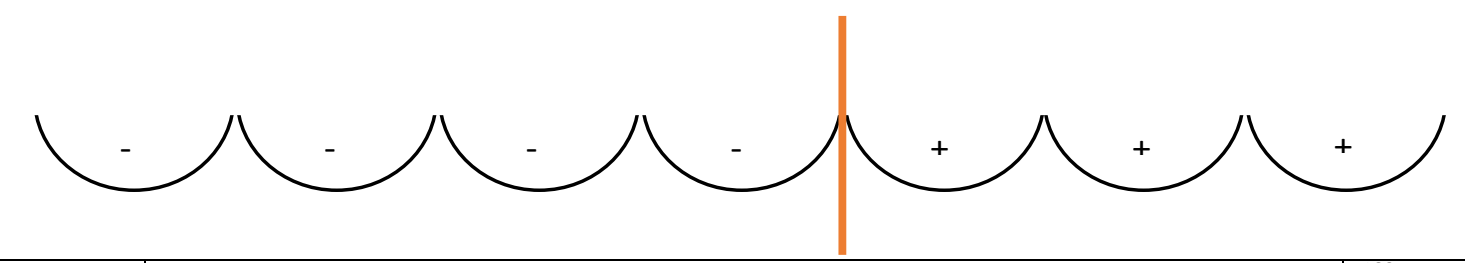

\begin{tabular}{|l|l|l|}
\hline $\begin{array}{l}\text { Number of } \\
\text { Genes }\end{array}$ & $\begin{array}{l}\text { Two pancreatic } \alpha \text {-amylase genes and one salivary } \alpha \text {-amylase gene, at } \\
\text { chromosome 1p21. }\end{array}$ & 109 \\
\hline Evolution & $\begin{array}{l}\text { Salivary amylase gene has evolved from a pre-existing pancreatic amylase gene. } \\
\text { The alteration in tissue specificity is probably due to retroviral insertion upstream } \\
\text { of the amylase gene }\end{array}$ & 109 \\
\hline $\begin{array}{l}\text { Domain } \\
\text { structure }\end{array}$ & $\begin{array}{l}\text { Domain A (residues 1-99, 170-404) has an eight-stranded parallel } \beta \text {-barrels in the } \\
\text { centre of } \alpha \text {-helical segments. This } \alpha \beta \text { architecture forms different subsites of the } \\
\text { active site (Figure } 1 \text { b.). Domain B (100-168) forms a large loop between the third } \\
\beta \text {-strand and the } \alpha \text {-helix. Domain C (405-496) consists of a } \beta \text {-stranded structure } \\
\text { (Figure } 1 \text { a.) }\end{array}$ & $19,110,111$ \\
\hline $\begin{array}{l}\text { Homology } \\
\text { significance }\end{array}$ & $\begin{array}{l}\text { Salivary and pancreatic } \alpha \text {-amylase have } 97 \% \text { homology with each other. A total of } \\
\text { side chains to the salivary amylase }\end{array}$ & $\begin{array}{l}19,110 \\
\text { the amino acid sequence that connects the A domain and C domain. }\end{array}$ \\
\hline $\begin{array}{l}\text { Clinical } \\
\text { application }\end{array}$ & $\begin{array}{l}\text { Two of these substitutions Thr } 163 \rightarrow \text { Ser and Leu } 196 \text { lle have a direct effect on } \\
\text { substrate binding, and different specificities to length of polysaccharides. }\end{array}$ & 19 \\
\hline $\begin{array}{l}\text { Post } \\
\text { translational } \\
\text { modifications }\end{array}$ & $\begin{array}{l}\text { In pancreatic } \alpha \text {-amylase, a carbon atom on the side chain of the terminal } \\
\text { glutamine residue and increases stability by providing protection against amino } \\
\text { peptidases. This post-translational modification appears to be specific to } \\
\text { pancreatic (as opposed to salivary) amylase. }\end{array}$ & 19 \\
\hline
\end{tabular}

Figure 1: Systematic representation of the structure of human $\alpha$-amylase (a) Amino acid sequence of human $\alpha$-amylase indicating the binding sites for Calcium (orange arrows), Chloride (black arrows) and $\mathrm{N}$-glycosylation sites (blue arrows) (b) Active site is a V-shaped cleft subdivided into different sub-sites, glycone, individual sugar residues in a oligosaccharide chain (-4,-3,-2 and -1) and aglycone, individual sugar residues after hydrolysis of glycosidic bond $(+1,+2$ and +3$)$. Each sub-site interacts with a monosaccharide and cleavage occurs between +1 and -1 , shown in the figure by the orange line. (C) Important difference from human pancreatic to salivary amylase are listed herein. 

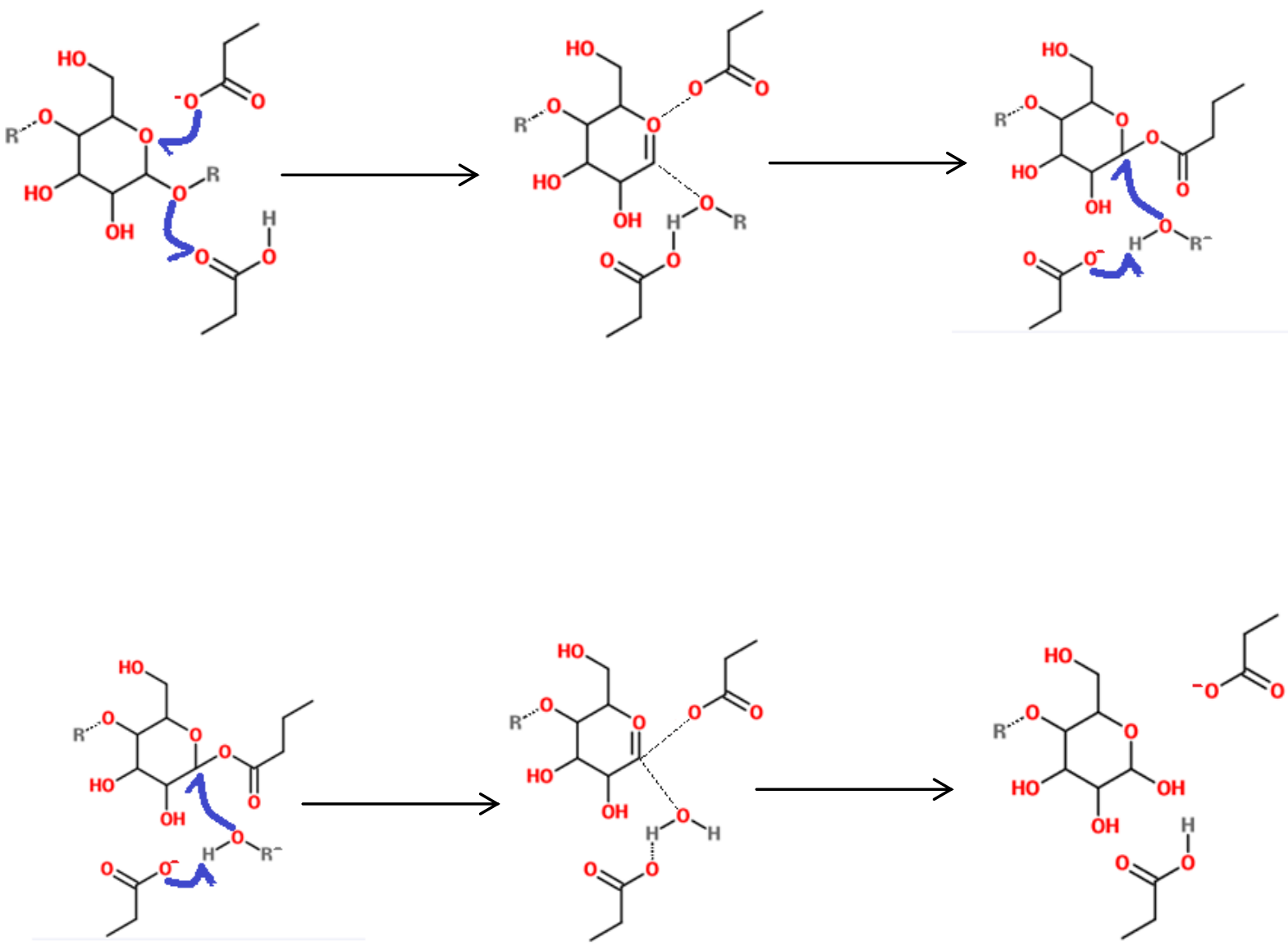

Figure 2: Schematic representation for the hydrolysis of glycosidic linkages by amylase. (a) The first displacement mechanism. The acid group of $\alpha$-amylase reacts with the glyosidic oxygen to form an oxcarbenium ion-like transition state. This goes through nucleophilic attach by the acid of $\alpha$-amylase to give a $\beta$-glycosyl enzyme intermediate. (b) The $\beta$-glycosyl enzyme intermediate reacts with activated $\mathrm{H}_{2} \mathrm{O}$ which forms an oxcarbenium ion-like transition state. The acid group of $\alpha$-amylase is then reprotonated. Most forms of $\alpha$-amylase are endo-enzymes, acting on substrate bonds within the 
carbohydrate chains, rather than those at the terminal ends. In contrast, maltogenic amylase is an exoenzyme subclass which hydrolyses terminal end residues which lead to them being re-classified as maltogenic amylases.

\section{Tables}

Table 1: Current classifications of Amylolytic Enzymes

\begin{tabular}{|c|c|}
\hline Subtheme & Current Trends in Literature \\
\hline Homology & $\begin{array}{l}\text { Minimal amino acid sequence homology but high homology in polypeptide } \\
\text { folding. Example: } \alpha \text {-amylase very similar active site centred around three } \\
\text { conserved carboxylate groups. Four segments with of sequence with good } \\
\text { homology; } 96-101,193-201,233-236 \text { and } 294-301 .{ }^{112,113}\end{array}$ \\
\hline Classification method & $\begin{array}{l}\text { IUB method does not take into account evolutionary events. Amylolytic enzymes } \\
\text { characterized on amino acid sequence homology, reaction mechanism, three } \\
\text { dimensional structure and active sites. }{ }^{15,16}\end{array}$ \\
\hline Number of families & $\begin{array}{l}1991 \text { found } 35 \text { different glycoside hydrolase families looking at sequence } \\
\text { homology }{ }^{15} \text {. Over } 950 \text { glycosyl hydrolases have been sequenced }{ }^{113-115} \text { to date. }\end{array}$ \\
\hline Family similarities & $\begin{array}{l}\text { Three dimensional structure suggests that families may be related to each other. } \\
\text { For example, families } 19,22,23 \text { and } 24 .^{115}\end{array}$ \\
\hline CAZy database & $\begin{array}{l}\text { Contains family divisions based on amino acid sequence of all CAZymes. In 2009, } \\
\text { the database covered } 300 \text { protein families including glycosyltransferases, } \\
\text { polysaccharide lyases and glycoside hydrolase. }{ }^{116} \text { In } 2013 \text {, there were } 330 \\
\text { families and over } 340000 \text { CAZymes with sequence information. }{ }^{117} \alpha \text {-amylase falls } \\
\text { into the glycoside hydrolase family } 13^{110} \text {. }\end{array}$ \\
\hline
\end{tabular}

CAZy $=$ carbohydrate-active enZymes 
Table 2: Pathophysiological states affecting plasma amylase levels other than pancreatic and salivary

\begin{tabular}{ll}
\hline Disease & a-amylase activity \\
\hline Diabetes Mellitus & $\begin{array}{l}\text { A study of } 9340 \text { diabetics } 1102 \text { (11.8\%) had elevated } \alpha \text {-amylase of that, } 22.3 \\
(4.1 \%) \text { had abnormal renal function. }\end{array}$ \\
Sjögren's Syndrome & $\begin{array}{l}24 \% \text { of patients with Sjögren's syndrome have persistent hyperamylasemia of } \\
\text { either isotype, pancreatic or salivary. Related to a moderate subclinical } \\
\text { inflammatory progression. }\end{array}$ \\
Inflammatory Bowel & $\begin{array}{l}\text { Increased serum amylase after treatment of ulcerative colitis by azathioprine. } \\
\text { Disease }\end{array}$ \\
$\begin{array}{l}\text { Serum amylase was increased (149 U/L) but amylase was absent in the urine. } \\
\text { This could potentially indicate the presence of macroamylasemia. Another } \\
\text { case report showed similar results. }\end{array}$
\end{tabular}

Renal Failure

This may be due to a decreased clearance level of the kidneys. Hussein et al. thought that elevated serum amylase could be due to pancreatic damage due to reactive oxygen species. Renal failure increases the oxidative stress and inflammatory states of the pancreas.

Peptic Ulcer

Non-alcoholic Fatty Liver Disease

Coeliac

Motamedi et al. found salivary amylase activity to be increased, possibly because of oxidative stress from the peptic ulcers.

Manifestation of a metabolic syndrome and insulin resistance. It has been shown to be related to low serum amylase levels independent of MetS, type 2 diabetes, and obesity.

Coeliac disease linked to hyperamylasemia and macroamylasemia

Familial

Hyperamylasaemia

Gullo et al. first described this condition from studying 18 patients who had increased amylase levels for a mean of 7.6 years. Two case studies were next to describe this condition in two young boys with abdominal pains and increased serum amylase. Both concluded it to be familial hyperamylasaemia and it to be autosomal dominant.

Chronic Physiological Stress

Increased serum amylase have been reported with increased stress, however, results are contended.

Acute HIV

A study of 94 HIV patients 7.5 (8\%) patients have increased serum $\alpha$-amylase pre-treatment, versus a study of 1368 HIV patients, 916.5 (67\%) patients had increased serum $\alpha$-amylase activity peri/post treatment, suggesting this increase is partially due to treatment options. Amylase activity may be as increased as $535 \mathrm{IU} / \mathrm{L}$.

Bacterial Infection

Bacillus, Clostridium and Aeromonas spp. constitutively produce amylase.

*Variations in amylase activity with pancreatic disease are extensively discussed elsewhere. CFTR $=$ Cystic Fibrosis Transmembrane Regulator. MetS = Metabolic syndrome 
Supplementary material: State of the art in currently available amylase detection technique

\begin{tabular}{|c|c|c|c|c|c|c|c|}
\hline \multirow[t]{2}{*}{ Assay } & \multirow{2}{*}{\multicolumn{2}{|c|}{ Design }} & \multicolumn{2}{|l|}{ Detection } & \multirow[t]{2}{*}{ Limits of detection } & \multirow[t]{2}{*}{ Specificity } & \multirow[t]{2}{*}{ Ref } \\
\hline & & & Sequential Process & Technique & & & \\
\hline \multicolumn{3}{|c|}{$\begin{array}{ll}\begin{array}{l}\text { Rate of product } \\
\text { formation }\end{array} & \begin{array}{l}\text { le and } \\
\text { le with }\end{array} \\
\text { glucosidase and } & x \text { - } \\
\text { optionally mutarotase } \\
\text { cross-linked by gelatin- } \\
\text { glutaraldehyde }\end{array}$} & $\begin{array}{l}\alpha \text {-glucosidase } \\
\text { converts maltose to } \\
\alpha \text {-D-glucose. } \\
\text { Mutarotase } \\
\text { converts } \alpha-D \text { - } \\
\text { glucose to } \beta \text {-D- } \\
\text { glucose which is } \\
\text { determined via } \\
\text { glucose oxidase }\end{array}$ & AMP & $\begin{array}{l}\text { LOD: } 2 \text { nkat } / \mathrm{mL} \\
(0.117 .64 \text { units } / \mathrm{mL} \text { ) } \\
\text { when reaction time } \\
5 \text { min } \\
0.5 \text { nkat } / \mathrm{mL} \\
\text { (0.02941 units } / \mathrm{mL} \text { ) } \\
\text { when reaction time } \\
30 \text { min }\end{array}$ & $\begin{array}{l}\text { Any } \alpha- \\
\text { amylase }\end{array}$ & 141 \\
\hline & \multicolumn{2}{|c|}{$\begin{array}{l}\text { Screen-printed } \\
\text { electrodes with } \\
\text { immobilized } \alpha \text { - } \\
\text { glucosidase, glucose } \\
\text { oxidase and mutarotase } \\
\text { modified with Prussian } \\
\text { Blue }\end{array}$} & $\begin{array}{l}\alpha \text {-glucosidase } \\
\text { converts maltose to } \\
\alpha \text {-D-glucose. } \\
\text { Mutarotase } \\
\text { converts } \alpha-D \text { - } \\
\text { glucose to } \beta \text {-D- } \\
\text { glucose which is } \\
\text { determined via } \\
\text { glucose oxidase }\end{array}$ & AMP & $\begin{array}{l}\text { LR: } 0.1-3 \mathrm{mmol} / \mathrm{L} \\
\text { LOD: } 5 \text { units/mL } \\
\text { LR: } 5-250 \text { units/mL }\end{array}$ & $\begin{array}{l}\text { Any } \alpha- \\
\text { amylase }\end{array}$ & 142 \\
\hline & \multicolumn{2}{|c|}{$\begin{array}{l}\text { Flow-injection device } \\
\text { using maltopentaose as } \\
\text { substrate. } \alpha \text {-glucosidase } \\
\text { immobilised on pre- } \\
\text { activated membrane. } \\
\text { Glucose oxidase } \\
\text { immobilized on } \\
\text { electrode }\end{array}$} & $\begin{array}{l}\alpha \text {-glucosidase } \\
\text { converts maltose to } \\
5 \text {-d-glucose. } \\
\text { Glucose oxidase } \\
\text { coverts 5-d-glucose } \\
\text { to gluconic acid and } \\
\text { hydrogen peroxide } \\
\text { which is measured }\end{array}$ & AMP & $\begin{array}{l}\text { LOD: } \\
\text { LR: 0-30 units/mL }\end{array}$ & $\begin{array}{l}\text { Any } \alpha- \\
\text { amylase }\end{array}$ & 143 \\
\hline & \multicolumn{2}{|c|}{$\begin{array}{l}\text { Spectrophotometric flow } \\
\text { injection measuring brick } \\
\text { red complex formation } \\
\text { at } 540 \mathrm{~nm}\end{array}$} & $\begin{array}{l}\text { Amylose incubated } \\
\text { with sample to } \\
\text { produce maltose. } \\
3,5 \text { dinitrosalicylic- } \\
\text { acid and maltose } \\
\text { boiled }\end{array}$ & SIA/FIA & $\begin{array}{l}\text { LOD: 0.0048 FAU } \\
\text { LR: 0.005-0.06 FAU }\end{array}$ & $\begin{array}{l}\text { Any } \alpha- \\
\text { amylase }\end{array}$ & 144 \\
\hline & \multicolumn{2}{|c|}{$\begin{array}{l}\text { Use of portable personal } \\
\text { glucose meter }\end{array}$} & $\begin{array}{l}\text { Sample, } \alpha- \\
\text { glucosidase and } \\
\text { maltopentaose } \\
\text { incubated } 15 \text { min at } \\
37^{\circ} \mathrm{C} \text {. }\end{array}$ & & $\begin{array}{l}\text { LOD: } 20 \mathrm{U} / \mathrm{L} \\
\text { LR: } 2.2-27.8 \mathrm{mM}\end{array}$ & $\begin{array}{l}\text { Any } \alpha- \\
\text { amylase }\end{array}$ & 145 \\
\hline & \multicolumn{2}{|c|}{$\begin{array}{l}\text { Flat-chip micro analytical } \\
\text { sensor used as part of a } \\
\text { Micro-Electro- } \\
\text { Mechanical Systems. } \\
\text { Pre-column and flat- } \\
\text { enzyme electrode } \\
\text { incorporated into a flow } \\
\text { cell where maltose }\end{array}$} & $\begin{array}{l}\text { Maltose } \\
\text { phosphorylase } \\
\text { phosphorylates } \\
\text { maltose. Glucose } \\
\text { oxidase converts } \\
\text { phosphorylated } \\
\text { maltose to } \\
\text { gluconic acid and }\end{array}$ & $\begin{array}{l}\text { Electroche } \\
\text { mical and } \\
\text { Lateral } \\
\text { flow }\end{array}$ & LR: 0-190 kU/L & $\begin{array}{l}\text { Any } \alpha- \\
\text { amylase }\end{array}$ & 143 \\
\hline
\end{tabular}




\begin{tabular}{|c|c|c|c|c|c|}
\hline $\begin{array}{l}\text { phosphorylase, glucose } \\
\text { oxidase and peroxidase } \\
\text { immobilised }\end{array}$ & $\begin{array}{l}\text { hydrogen peroxide } \\
\text { which is measured }\end{array}$ & & & & \\
\hline $\begin{array}{l}\text { Colorimetric assay } \\
\text { biosensor system using } \\
\text { Gal-G2-CNP, } \\
\text { chromogenic substrate } \\
\text { for } \alpha \text {-amylase. CNP is a } \\
\text { yellow product once } \\
\text { hydrolysed which can be } \\
\text { measured } \\
\text { photometrically at } \\
430 \mathrm{~nm} \text {. }\end{array}$ & $\begin{array}{l}\text { Disposable test } \\
\text { strip placed under } \\
\text { tongue }(25 \mu \mathrm{l}) \text {. } \\
\text { Once strip inserted } \\
\text { into reader and } \\
\text { saliva moved onto } \\
\text { the reagent paper. } \\
\text { The entire test } \\
\text { takes roughly } 30 \\
\text { sec. }\end{array}$ & AMP & LR: $10-230 \mathrm{U} / \mathrm{mL}$ & $\begin{array}{l}\text { Any } \alpha- \\
\text { amylase }\end{array}$ & 146 \\
\hline $\begin{array}{cl}\text { Rate of starch digestion } & \text { :ric } \\
& \text { । starch- } \\
\text { iodine complexes }\end{array}$ & $\begin{array}{l}\text { Sample } \\
\text { degradation of } \\
\text { complexes } \\
\text { measured in flow } \\
\text { channel }\end{array}$ & FIA & $\begin{array}{l}\text { LOD: } 60 \mathrm{NU} / \mathrm{mL} \\
\text { LR: } 0.25-5.0 \\
\mathrm{KNU} / \mathrm{mL}\end{array}$ & $\begin{array}{l}\text { Any } \alpha- \\
\text { amylase }\end{array}$ & 147 \\
\hline $\begin{array}{l}\text { Immobilized layer of } \\
\text { starch gel on thick-film } \\
\text { magneto elastic sensor } \\
\text { and presence of } \alpha \text { - } \\
\text { amylase alters the } \\
\text { resonance frequency }\end{array}$ & $\begin{array}{l}\text { Sample placed on } \\
\text { starch gel }\end{array}$ & & LR: $75-125 \mathrm{U} / \mathrm{mL}$ & $\begin{array}{l}\text { Any } \alpha- \\
\text { amylase }\end{array}$ & 148 \\
\hline $\begin{array}{l}\text { Spectrofluorimetric } \\
\text { using the quenching of } \\
\text { luminescence intensity } \\
(634 \mathrm{~nm}) \text { of nano } \mathrm{CdS} \\
\text { doped in sol-gel of } \\
\text { different concentrations } \\
\text { of maltose }\end{array}$ & $\begin{array}{l}\text { Sample incubated } \\
\text { with starch in flow } \\
\text { channels }\end{array}$ & FIA & $\begin{array}{l}\text { LOD: } 5.7 \times 10^{-11} \\
\mathrm{~mol} / \mathrm{L} \\
\text { LR: } 4.8 \times 10^{-10}-1.2 \\
\times 10^{-5} \mathrm{~mol} / \mathrm{L}\end{array}$ & $\begin{array}{l}\text { Any } \alpha- \\
\text { amylase }\end{array}$ & 149 \\
\hline $\begin{array}{l}\text { Glycogen/amylopectin } \\
\text { spin-coated on gold } \\
\text { coated quartz crystals } \\
\text { (case frequency of } 10 \\
\text { MHz). Films cross-linked } \\
\text { with hexamethylene } \\
\text { diisocyanate. Film } \\
\text { degradation measured } \\
\text { with quartz crystal } \\
\text { microbalance }\end{array}$ & $\begin{array}{l}\text { Sample incubated } \\
\text { with film }\end{array}$ & EIS & & $\begin{array}{l}\text { Any } \alpha- \\
\text { amylase }\end{array}$ & 150 \\
\hline $\begin{array}{l}\text { Degradation of starch- } \\
\text { triiodide measured using } \\
\text { platinum redox sensor } \\
\text { for direct potentiometric } \\
\text { determination }\end{array}$ & $\begin{array}{l}\text { Sample incubated } \\
\text { with starch- } \\
\text { triiodide }\end{array}$ & & $\begin{array}{l}\text { LOD: } 1.944 \mathrm{mU} \\
\text { LR: 0-0.54 U }\end{array}$ & $\begin{array}{l}\text { Any } \alpha- \\
\text { amylase }\end{array}$ & 151 \\
\hline $\begin{array}{l}\text { Glucose oxidase-based } \\
\text { biosensor measuring the } \\
\text { decrease in dissolved } \\
\text { oxygen concentration } \\
\text { related to starch } \\
\text { concentration. }\end{array}$ & & & $\begin{array}{l}\text { LOD: } \\
\text { LR: } 0.66-9.83 \mathrm{U} / \mathrm{mL}\end{array}$ & $\begin{array}{l}\text { Any } \alpha- \\
\text { amylase }\end{array}$ & 152 \\
\hline
\end{tabular}




\section{References:}

1. Fife CE, Carter MJ, Walker D, Thomson B. Wound care outcomes and associated cost among patients treated in US outpatient wound centers: data from the US wound registry. Wounds. 2012;24:10-7.

2. Azzopardi EA, Azzopardi E, Camilleri L, Villapalos J, Boyce DE, Dziewulski P, et al. Gram Negative Wound Infection in Hospitalised Adult Burn Patients-Systematic Review and Metanalysis. PloS one. 2014;9:e95042.

3. Azzopardi EA, Ferguson EL, Thomas DW. Colistin past and future: A bibliographic analysis. Journal of Critical Care. 2013;28:219. e13-. e19.

4. Boucher HW, Talbot GH, Bradley JS, Edwards JE, Gilbert D, Rice LB, et al. Bad bugs, no drugs: no ESKAPE! An update from the Infectious Diseases Society of America. Clin Infect Dis. 2009;48:112.

5. Worldwide Cancer Key Stats. Key Stats. CancerStats: Cancer Research UK; 2014.

6. Spellberg B, Bartlett J, Gilbert D. The Future of Antibiotics and Resistance. The New England Journal of Medicine. 2013;368:299-302.

7. Spellberg B, Guidos R, Gilbert D, Bradley J, Boucher H, Scheld W, et al. The Epidemic of Antibiotic-Resistant Infections: A Call to Action for the Medical Community from the Infectious Diseases Society of America. Clinical Infectious Diseases. 2008;46:155-64.

8. Antimicrobial Resistance: A Problem Without Borders. The Richard \& Hinda Rosenthal Symposium 2014. 2014:46.

9. $\quad$ Friedberg F. The remarkable amylases. Biochemical Education. 1985;13:105-7.

10. Steinberg W, DeVries JH, Wadden TA, Jensen CB, Svendsen CB, Rosenstock J. Tu1502 Longitudinal Monitoring of Lipase and Amylase in Adults With Type 2 Diabetes and Obesity: Evidence From Two Phase 3 Randomized Clinical Trials With the Once-Daily GLP-1 Analog Liraglutide. Gastroenterology. 2012;142:S-850. 
11. Seetharaman K, Bertoft E. Perspectives on the history of research on starch Part II: On the discovery of the constitution of diastase. Starch-Stärke. 2012;64:765-9.

12. National Library of Medicine. MeSH Browser.

2009.

13. MacGregor E, Janecek S, Svensson B. Relationship of Sequence and Structure to Specificity in the $\alpha$-amylase Family of Enzymes. Protein Structure and Molecular Enzymology. 2001;1546:1-20.

14. Miyake H, Kurisu G, Kusunoki M, Nishimura S, Kitamura S, Nitta Y. Crystal Structure of a Catalytic Site Mutant of Beta-amylase from Bacillus Cereus Var. Mycoides Cocrystallized with Maltopentaose. Biochemsitry. 2003;42:5574-81.

15. Henrissat B. A Classification of Glycosyl Hydrolases based on Amino Acid Sequence Similarites. Biochemistry Journal. 1991;280:309-16.

16. Janecek S, Svensson B, MacGregor A. $\alpha$-Amylase: an Enzyme Specificity Found in Various Families of Glycoside Hydrolases. Cellular and Molecular Life Sciences. 2014;71:1149-70.

17. Ferey-Roux G, Perrier J, Forest E, Marchie-Mouren G, Puigserver A, Santimone M. The Human $\alpha$ amylase Isoforms: Isolation, Structural Studies and Kinetics of Inhibition by Acarbose. Protein Structure and Molecular Enzymology. 1998;1388:10-20.

18. Whitcomb D, Lowe M. Human Pancreatic Digestive Enzymes. Digestive Diseases and Sciences. 2007;52:1-17.

19. Brayer G, Luo Y, Withers S. The Structure of Human Pancreatic Alpha-amylase at $1.8 \mathrm{~A}$ Resolution and Comparisons with Related Enzymes. Protein Science. 1995;4:1730-42.

20. Vipin AK, Hu B, Fugetsu B. Prussian blue caged in alginate/calcium beads as adsorbents for removal of cesium ions from contaminated water. Journal of hazardous materials. 2013;258:93101.

21. Horsman SR, Moore RA, Lewenza S. Calcium chelation by alginate activates the type III secretion system in mucoid Pseudomonas aeruginosa biofilms. 2012.

22. Worthington Inc. Effect of pH on amylase. 2015.

23. Nakajima K, Oshida H, Muneyuki T, Saito M, Hori Y, Fuchigami H, et al. Independent Association between Low Serum Amylase and Non-Alcoholic Fatty Liver Disease in Asymptomatic Adults: a Cross-Sectional Observational Study. BMJ Open. 2013;3:e002235.

24. Depsames R, Fireman Z, Niv E, Kopelman Y. Macromylasemia as the First Manifestation of Celiac Disease. Case Reports in Gastroenterology. 2008;2:196-8.

25. Liu Z, Wang J, Qian J, Tang F. Hyperamylasemia, Reactive Plasmacytosis, and Immune Abnormalities in a Patient with Celiac Disease. Digestive Diseases and Sciences. 2007;52:1444-7.

26. Venkataraman D, Howarth L, Beattie R, Afzal A. A Very High Amylase can be Benign in Paediatric Crohn's Disease. BMJ Case Reports. 2012.

27. Rosenblum J. Serum Lipase Activity is Increased in Disease States other than Acute Pancreatitis: Amylase Revisited. Clinical Chemistry. 1991;37:315-6.

28. Azzopardi EA, Ferguson EL, Thomas DW. The Enhanced Permeability Retention Effect: A New Paradigm for Drug Targeting in Infection. Journal of Antimicrobial Chemotherapy. 2012; In Press.

29. Ferguson E, Walsh T, Thomas D. Therapeutic conjugates. GB 1010500.5, PCT/GB2011/051029, WO/2012/035310. UK 2012.

30. Azzopardi E, Ferguson E, Thomas D. Polymer therapeutics for effective antimicrobial targeting in burn injury. BRITISH JOURNAL OF SURGERY: WILEY-BLACKWELL COMMERCE PLACE, 350 MAIN ST, MALDEN 02148, MA USA; 2011. p. 55-.

31. Azzopardi EA, Ferguson EL, Thomas DW. Development and Validation of an In Vitro Pharmacokinetic/Pharmacodynamic Model To Test the Antibacterial Efficacy of Antibiotic Polymer Conjugates. Antimicrobial agents and chemotherapy. 2015;59:1837-43. 
32. Shelley WB, Mescon $\mathrm{H}$. Histochemical demonstration of secretory activity in human eccrine sweat glands. J Invest Dermat. 1952;18:289-301.

33. Eguchi T, Ishikawa Y, Ishida H. Mechanism Underlying Histamine-induced Densenitization of Amylase Secretion in Rat Parotid Glands. British Journal of Pharmacology. 1998;124:1523-33.

34. Francis T, Graf A, Hodges K, Kennedy L, Hargrove L, Price M, et al. Histamine Regulation of Pancreatitis and Pancreatic Cancer: A Review of Recent Findings. Hepatobiliary Surgery and Nutrition. 2013;2:216-26.

35. MacGlashan D. Histamine: A mediator of Inflammation. American Academy of Allergy, Asthma and Immunology. 2003:s53-s9.

36. Couto S, Sanroman M. Application of solid-state fermentation to food industry-a review. Journal of Food Engineering. Journal of Food Engineering. 2006;76:291-302.

37. Snoeijers S, Perez-Garcia A, Joosten M, De Wit P. The effect of nitrogen on disease development and gene expression in bacterial and fungal plant pathogens. European Journal of Plant Pathology. 2000;106:493-506.

38. Yavankar S, Pardesi K, Chopade B. Species Distribution and Physiological Characterization of Acinetobacter Genospecies from Healthy Human Skin of Tribal Population in India. Indian Journal of Medical Microbiology. 2007;25:336-45.

39. Khannous L, Jrad M, Dammak M, Miladi R, Chaaben N, Khemakhem B, et al. Isolation of a Novel Amylase and Lipase-producing Pseudomonas luteola Strain: Study of Amylase Production Conditions. Lipids Health and Disease. 2014;13.

40. Rasiah I, Rehm B. One-step Production of Immobilized Alpha-amylase in Recombinant Escherichia coli. Applied Environmental Microbiology. 2009;75:2012-6.

41. Pohl S, Harwood C. Chapter 1 - Heterologous Protein Secretion by Bacillus Species: From the Cradle to the Grave. Advances in Applied Microbiology. 2010;73:1-25.

42. Urbina P, Collado MI, Alonso A, Goni FM, Flores-Diaz M, Alape-Giron A, et al. Unexpected wide substrate specificity of $C$. perfringens alpha-toxin phospholipase C. Biochimica et biophysica acta. 2011;1808:2618-27.

43. Brook I. Current concepts in the management of Clostridium tetani infection. Expert review of anti-infective therapy. 2008;6:327-36.

44. Vidor C, Awad M, Lyras D. Antibiotic resistance, virulence factors and genetics of Clostridium sordellii. Research in microbiology. 2014.

45. Goudarzi M, Seyedjavadi SS, Goudarzi H, Mehdizadeh Aghdam E, Nazeri S. Clostridium difficile Infection: Epidemiology, Pathogenesis, Risk Factors, and Therapeutic Options. Scientifica. 2014;2014:916826.

46. Sharma SK, Basavanna U, Shukla HD. Protein Domain Analysis of C. botulinum Type A Neurotoxin and Its Relationship with Other Botulinum Serotypes. Toxins. 2010;2:1-9.

47. Sarvas M, Harwood C, Bron S, Diji J. Post-translocational Folding of Secretory Proteins in Grampositive Bacteria. Molecular Cell Research. 2004;1694:311-27.

48. Chen E, Deng L, Liu Z, Zhu X, Chen X, Tang H. Management of gas gangrene in Wenchuan earthquake victims. J Huazhong Univ Sci Technol [Med Sci]. 2011;31:83-7.

49. Pettitt DA, Molajo A, McArthur P. A human bite. BMJ. 2012;345.

50. Bakker DJ. Clostridial myonecrosis (gas gangrene). Undersea and Hyperbaric Medicine. 2012;39:731.

51. Weinstein L, Barza MA. Gas gangrene. The New England journal of medicine. 1973;289:1129.

52. Permpoonpattana $\mathrm{P}, \mathrm{Hong} \mathrm{H}$, Khaneja $\mathrm{R}$, Cutting $\mathrm{S}$. Evaluation of Bacillus subtilis strains as probiotics and their potential as a food ingredient. Beneficial microbes. 2012;3:127-35. 
53. Soni SK, Goyal N, Gupta JK, Soni R. Enhanced production of $\alpha$-amylase from Bacillus subtilis subsp. spizizenii in solid state fermentation by response surface methodology and its evaluation in the hydrolysis of raw potato starch. Starch-Stärke. 2012;64:64-77.

54. Emele FE. Rapid iodometric detection of Aeromonas amylase and its diagnostic significance. Diagnostic Microbiology and Infectious Disease.40:91-4.

55. Gurung N, Ray S, Bose S, Rai V. A broader view: microbial enzymes and their relevance in industries, medicine, and beyond. BioMed research international. 2013;2013.

56. Whitaker IS, Oboumarzouk O, Rozen WM, Naderi N, Balasubramanian S, Azzopardi EA, et al. The efficacy of medicinal leeches in plastic and reconstructive surgery: a systematic review of 277 reported clinical cases. Microsurgery. 2012;32:240-50.

57. Azzopardi EA, Azzopardi SM, Boyce DE, Dickson WA. Emerging gram-negative infections in burn wounds. Journal of Burn Care \& Research. 2011;32:570-6.

58. Maeda H. Macromolecular therapeutics in cancer treatment: the EPR effect and beyond. Journal of Controlled Release. 2012;164:138-44.

59. Fong J, Ferraro DJ, Hunn J, Roberts S, Berezin MY, Rogers BE, et al. Radiation increases permeability and retention of PEG-conjugates in solid tumors. Cancer Research. 2013;73:2666-.

60. Vicent MJ, Duncan R. Polymer conjugates: nanosized medicines for treating cancer. Trends in biotechnology. 2006;24:39-47.

61. Brown CB, Luciano AA, Martin D, Peers E, Scrimgeour A, Group AARS. Adept (icodextrin $4 \%$ solution) reduces adhesions after laparoscopic surgery for adhesiolysis: a double-blind, randomized, controlled study. Fertility and sterility. 2007;88:1413-26.

62. Barenholz YC. Doxil ${ }^{\oplus}$ - the first FDA-approved nano-drug: lessons learned. Journal of Controlled Release. 2012;160:117-34.

63. Federal Drug Agency. FDA approved drug products-icodextrin. 2010.

64. Guo A, Wolfson M, Holt R. Early quality of life benefits of icodextrin in peritoneal dialysis. Kidney International. 2002;62:S72-S9.

65. Woolfson A, Ricketts C, Hardy S, Saour J, Pollard B, Allision S. Prolonged nasogastric tube feeding in critically ill and surgical patients. . Postgraduate Medical Journal. 1976; 52.

66. Davies SJ. Exploring new evidence of the clinical benefits of icodextrin solutions. Nephrology Dialysis Transplantation. 2006;21 Suppl 2:ii47-50.

67. Kerr D, Young A, Neoptolemos J, Sherman M, Van-Geene P, Stanley A, et al. Prolonged intraperitoneal infusion of 5-fluorouracil using a novel carrier solution. British journal of cancer. 1996;74:2032.

68. Peers E, Gokal R. Icodextrin provides long dwell peritoneal dialysis and maintenance of intraperitoneal volume. Artificial organs. 2008;22:8-12.

69. Boury B, Plumejeau S. Metal oxides and polysaccharides: an efficient hybrid association for materials chemistry. Green Chemistry. 2015;17:72-88.

70. Riva FM, Chen YC, Tan NC, Lin PY, Tsai YT, Chang HW, et al. The outcome of prostaglandin-E1 and dextran-40 compared to no antithrombotic therapy in head and neck free tissue transfer: Analysis of 1,351 cases in a single center. Microsurgery. 2012;32:339-43.

71. Burkart J. Metabolic consequences of peritoneal dialysis. . Seminars in Dialysis. 2004; 6.

72. Davies DS. Kinetics of icodextrin. Perit Dial Int. 1993;14:S45-S50.

73. Roberts $P$, Whelan W. The mechanism of carboydrase action. Biochemistry Journal 1960;76.

74. Duncan R, Gaspar R. Nanomedicine (s) under the Microscope. Molecular Pharmaceutics. 2011;8:2101-41.

75. Duncan R. Polymer therapeutics as nanomedicines: new perspectives. Current Opinion in Biotechnology. 2011;22:492-501. 
76. Azzopardi EA, Camilleri L, Moseley R, Thomas DW, Ferguson EL. Statistical characterization of succinoylated dextrin degradation behavior in human $\alpha$-amylase. Journal of Carbohydrate Chemistry. 2013;32:438-49.

77. Azzopardi E, Ferguson E, Thomas D. A novel class of bioreponsive nanomedicines for localised reinstatement of bioactivity and specific targeting. The Lancet. 2014;383:S9.

78. Duncan R, Vicent MJ. Polymer therapeutics-prospects for 21st century: the end of the beginning. Advanced drug delivery reviews. 2013;65:60-70.

79. Duncan R, Gaspar R. Nanomedicine (s) under the Microscope. Molecular Pharmaceutics. 2011.

80. Ferguson EL, Azzopardi E, Roberts JL, Walsh TR, Thomas DW. Dextrin-colistin conjugates as a model bioresponsive treatment for multidrug resistant bacterial infections. Molecular Pharmaceutics. 2014;11:4437-47.

81. Duncan R, Gilbert H, Carbajo R, Vicent M. Polymer Masked-Unmasked Protein Therapy. 1. Bioresponsive Dextrin- Trypsin and -Melanocyte Stimulating Hormone Conjugates Designed for $\alpha$-amylase Activation. Biomacromolecules. 2008;9:1146-54.

82. Duncan R, Gilbert H, Carbajo R, Vicent M. Polymer Masked- Unmasked Protein Therapy. 1. Bioresponsive Dextrin- Trypsin and- Melanocyte Stimulating Hormone Conjugates Designed for Amylase Activation. Biomacromolecules. 2008;9:1146-54.

83. Hardwicke J, Ferguson E, Moseley R, Stephens P, Thomas D, Duncan R. Dextrin-rhEGF Conjugates as Bioresponsive Nanomedicines for Wound Repair. Journal of Controlled Release. 2008;130:275-83.

84. Ferguson EL, Azzopardi E, Roberts JL, Walsh TR, Thomas DW. Dextrin-colistin conjugates as a model bioresponsive treatment for multidrug resistant bacterial infections. Mol Pharm. 2014;11:4437-47.

85. Azzopardi EA, Ferguson EL, Thomas DW. Development and Validation of an In Vitro Pharmacokinetic/Pharmacodynamic Model to Test the Antibacterial Efficacy of Antibiotic Polymer Conjugates. Antimicrobial agents and chemotherapy. 2014:AAC. 03708-14.

86. Hardwicke J, Moseley R, Stephens P, Harding K, Duncan R, Thomas D. Bioresponsive DextrinrhEGF Conjugates: In Vitro Evaluation in Models Relevant to its Proposed Use as a Treatment for Chronic Wounds. Molecular Pharmaceuticals. 2010;7:699-707.

87. Ferguson E, Duncan R. Dextrin-Phospholipase $\mathrm{A}_{2}$ : Synthesis and Evalution as a Bioresponsive Anticancer Conjugate. Biomacromolecules. 2009;10:1358-64.

88. Marcinow AM, Hall N, Byrum E, Teknos TN, Old MO, Agrawal A. Use of a novel receptor-targeted (CD206) radiotracer, 99mTc-tilmanocept, and SPECT/CT for sentinel lymph node detection in oral cavity squamous cell carcinoma: initial institutional report in an ongoing phase 3 study. JAMA Otolaryngology-Head \& Neck Surgery. 2013;139:895-902.

89. Sondak VK, King DW, Zager JS, Schneebaum S, Kim J, Leong SP, et al. Combined analysis of Phase III trials evaluating [ $99 \mathrm{mTc}$ ] Tilmanocept and vital blue dye for identification of sentinel lymph nodes in clinically node-negative cutaneous melanoma. Annals of surgical oncology. 2013;20:680-8.

90. Greco F, Vicent MJ. Polymer-drug conjugates: current status and future trends. Frontiers in Bioscience. 2008:2744-56.

91. Sommermeyer K, Eichner W. Haemoglobin-hydroxyethyl starch conjugates as oxygen carriers. Google Patents; 2000.

92. Perner A, Haase N, Guttormsen AB, Tenhunen J, Klemenzson G, Åneman A, et al. Hydroxyethyl starch 130/0.42 versus Ringer's acetate in severe sepsis. New England Journal of Medicine. 2012;367:124-34.

93. Myburgh JA, Finfer S, Bellomo R, Billot L, Cass A, Gattas D, et al. Hydroxyethyl starch or saline for fluid resuscitation in intensive care. New England Journal of Medicine. 2012;367:1901-11. 


\section{Ferguson EL, Duncan R. Dextrin-phospholipase A2: synthesis and evaluation as a bioresponsive} anticancer conjugate. Biomacromolecules. 2009;10:1358-64.

95. Li L, Somerset S. Digestive system dysfunction in cystic fibrosis: challenges for nutrition therapy. Digestive and liver disease : official journal of the Italian Society of Gastroenterology and the Italian Association for the Study of the Liver. 2014;46:865-74.

96. Somaraju UR, Solis-Moya A. Pancreatic enzyme replacement therapy for people with cystic fibrosis. The Cochrane database of systematic reviews. 2014;10:CD008227.

97. Sales PM, Souza PM, Simeoni LA, Silveira D. alpha-Amylase inhibitors: a review of raw material and isolated compounds from plant source. Journal of pharmacy \& pharmaceutical sciences : a publication of the Canadian Society for Pharmaceutical Sciences, Societe canadienne des sciences pharmaceutiques. 2012;15:141-83.

98. de Sales P, de Souza P, Simeoni L, Magalhaes P, Silveira D. $\alpha$-amylase Inhibitors: A Review of Raw Material and Isolated Compounds from Plant Source. Journal of Pharmacy and Pharmaceutical Sciences. 2012;15:141-83.

99. de Gouveia N, Alves F, Furtado F, Scherer D, Mundim A, Espindola F. An In Vitro and In Vivo Study of the $\alpha$-amylase Activity of Phaseolamin. Journal of Medicinal Food. 2014;17:915-20.

100. Oliveira R, Oliveira V, Deconte S, Calabria L, Silva Moraes A, Espindola F. Phaseolamin Treatment Prevents Oxidative Stress and Collagen Deposition in the Hearts of Streptozotocin-induced Diabetic Rates. Diabetic Vascular Disease Research. 2014;11:110-7.

101. Candido G, Ton S, Alfenas G. Addition of Dietary Fiber Sources to Shakes Reduces Postprandial Glycemia and Alters Food Intake. Nutricion Hospitalaria. 2014;31:299-306.

102. Mendez M, Goni A, Ramirez W, Grau R. Sugar inhibits the production of the toxins that trigger clostridial gas gangrene. Microbial pathogenesis. 2012;52:85-91.

103. Maeda E, Kataoka M, Yatsushiro S, Kajimoto K, Hino M, Kaji N, et al. Accurate quantitation of salivary and pancreatic amylase activities in human plasma by microchip electrophoretic separation of the substrates and hydrolysates coupled with immunoinhibition. Electrophoresis. 2008;29:1902-9.

104. Morishita Y, linuma Y, Nakashima N, Majima K, Mizuguchi K, Kawamura Y. Total and pancreatic amylase measured with 2-chloro-4-nitrophenyl-4-O-beta-D-galactopyranosylmaltoside. Clin Chem. 2000;46:928-33.

105. Perich C, Ricós C, Alvarez V, Biosca C, Boned B, Cava F, et al. External quality assurance programs as a tool for verifying standardization of measurement procedures: Pilot collaboration in Europe. Clinica Chimica Acta. 2014;432:82-9.

106. Aluoch AO, Sadik OA, Bedi G. Development of an oral biosensor for salivary amylase using a monodispersed silver for signal amplification. Analytical biochemistry. 2005;340:136-44.

107. Wu S, Zhu Y, Cai Q, Zeng K, Grimes C. A Wireless Magnetoelastic $\alpha$-amylase Sensor. Sensors and Activators B. 2007;121:467-81.

108. Weitgasser R, Gappmayer B, Pichler M. Newer portable glucose meters-analytical improvement compared with previous generation devices? Clinical Chemistry. 1999;45:1821-5.

109. Meisler MH, Ting C-N. The remarkable evolutionary history of the human amylase genes. Critical Reviews in Oral Biology \& Medicine. 1993;4:503-9.

110. Ragunath C, Manuel S, Venkataraman V, Sait H, Kashinathan C, Ramasubbu N. Probing the Role of Aromatic Residues at the Secondary Saccharide-Binding Sites of Human Salivary Alphaamylase in Substrate Hydrolysis and Bacterial Binding. Journal of Molecular Biology. 2008;384:1232-48.

111. Fisher SZ, Govindasamy L, Tu C, Agbandje-McKenna M, Silverman DN, Rajaniemi HJ, et al. Structure of human salivary alpha-amylase crystallized in a C-centered monoclinic space group. 
Acta crystallographica Section F, Structural biology and crystallization communications. 2006;62:88-93.

112. Ramasubbu N, Ragunath C, Mishra P, Thomas L, Gyemant G, Kandra L. Human Salivary $\alpha$ amylase Trp58 Situated at Subsite -2 is Critical for Enzyme Activity European Journal of Biochemistry. 2004;271:2517-29.

113. Henrissat B, Bairoch A. New Families in the Classification of Glycosyl Hydrolases Based on Amino Acid Sequence Similarites. Biochemistry Journal. 1993;293:781-8.

114. Henrissat B, Romeu A. Families, Superfamilies and Subfamilies of Glycosyl Hydrolases. Biochemistry Journal. 1995;311:350-1.

115. Henrissat B, Bairoch A. Updating the Sequence-Based Classification of Glycosyl Hydrolases. Biochemistry Journal. 1996;316:695-6.

116. Cantarel B, Coutinho P, Rancurel C, Bernard T, Lombard V, Henrissat B. The Carbohydrate-Active EnZymes Database (CAZy): an Expert Resource for Glycogenomics. Nucleic Acids Research. 2009;37:D233-D8.

117. Lombard V, Ramulu H, Drula E, Coutinho P, Henrissat B. The Carbohydrate-Active Enzymes Database (CAZy) in 2013. Nucleic Acids Research. 2014;42:D490-D5.

118. Steinberg W, Nauck M, Zinman B, Daniels G, Bergenstal R, Mann J, et al. LEADER 3 - Lipase and Amylase Activity in Subjects With Type 2 Diabetes. Pancreas. 2014;43:1223-31.

119. Hernandez-Molina G, Michel-Peregrina M. Sjögren's Syndrome and Pancreatic Affection. Reumatologia Clinica. 2011;7:130-4.

120. Kaneko H, Ohkawara Y, Taniguchi K, Matsumoto Y, Nomura K, Horiike S, et al. Simultaneous Complication of Multiple Myeloma with Sögren Syndrome. Asian Pacific Journal of Allergy and Immunology. 2006;24:245-8.

121. Liverani E, Leonardi F, Castellani L, Cardamone C, Belluzzi A. Asymptomatic and Persistent Elevation of Pancreatic Enzymes in an Ulcerative Colitis Patient. Case Report Gastrointestinal Medicines. 2013;2013:415619.

122. Kum F, Gulati A, Hussain A. Hyperamylasaemia and Ischaemic Colitis. International Journal of Surgery - Case Report. 2014;5:63-6.

123. Khan F, Al-Ani A, Ali H. Typhoid Rhabdomyolysis with Acute Renal Failure and Acute Pancreatitis: a Case Report and Review of the Literature. International Journal of Infectious Diseases. 2009;13:e282-e5.

124. Hussein A, Abd-Elkhabir A, Abozahra A, Baiomy A, Ashamallah S, Sheashaa H, et al. Pancreatic Injury Secondary to Renal Ischemia/Reperfusion (I/R) Injury: Possible Role of Oxidative Stress. Physiology Research. 2014;63:47-55.

125. Motamedi M, Mansour-Ghanaei F, Sariri R, Vesal M. Salivary Enzymes in Peptic Ulcer Disease. Journal of Oral Biology and Craniofacial Research. 2013;3:83-7.

126. Lee K, Paik C, Chung W, Yang J. Association Between Acute Pancreatitis and Peptic Ulcer Disease. World Journal of Gastroenterology. 2011;17:1058-62.

127. Lin C, Wang Z, Lai K, Lo G, Hsu P. Gastrointestinal Mucosal Lesions in Patients with Acute Pancreatitis. Chinese Medical Journal. 2002;65:275-8.

128. Gullo L. Chronic Nonpathological Hyperamylasemia of Pancreatic Origin. Gastroenterology. 1996;110:1905-8.

129. Koda YKL, Vidolin E. Familial Hyperamylasemia. Revista do Hospital das Clinicas. 2002;54:77-82.

130. Cuckow P, Foo A, Jamal A, Stringer M. Familial Hyperamylasaemia. Gut. 1997;40:689-90.

131. Vineetha R, Keerthilatha-M P, Vengal M, Kodyalamoole G, Narayanakurup D. Usefulness of Salivary Alpha Amylase as a Biomarker of Chronic Stress and Stress Related Oral Mucosal Changes - a Pilot Study. Journal of Clinical and Experimental Dentistry. 2014;6:e132-e7. 
132. Allwood M, Handwerger K, Kivlighan K, Granger D, Stroud L. Direct and Moderating Links of Salivary Alpha-Amylase and Cortisol Stress-Reactivity to Youth Behavioral and Emotional Adjustment. Biological Psychology. 2011;88:57-64.

133. Koh D, Ng V, Naing L. Alpha Amylase as a Salivary Biomarker of Acute Stress of Venepuncture from Periodic Medical Examinations. Front Public Health. 2014;2:1-5.

134. Laurent H, Powers S, Granger D. Refining the Multisytem View of the Stress Response: Coordination Among Cortisol, Alpha-Amylase, and Subjective Stress in Response to Relationship Conflict. Physiology and Behavior. 2013;119:52-60.

135. Moore J, Schneider S. Acute Human Immunodeficiency Virus (HIV) Infection Presenting with Fever, Elevated Amylase/Lipase, and Hematologic Abnormalities. Journal of Emergency Medicine. 2013;44:e341-e4.

136. Moolla Z, Anderson F, Thomson S. Use of Amylase and Alanine Transaminase to Predict Acute Gallstone Pancreatitis in a Population with High HIV Prevalence. World Journal of Surgery. 2012;37:156-1661.

137. Lambertus M, Anderson R. Hyperamylasemia in Patients with Human Immunodeficiency Virus Infection. The New England Journal of Medicine. 1990;323:1708-9.

138. Ryan R, Dayaram Y, Schaible D, Coate B, Anderson D. Outcomes in Older Versus Younger Patients Over 96 Weeks in HIV-1- Infected Patients Treated with Rilpivirine or Efavirenz in ECHO and THRIVES. Current HIV Research. 2013;11:570-5.

139. Nanmori T, Nagai M, Shimizu Y, Shinke R, Mikami B. Cloning of the beta-amylase gene from Bacillus cereus and characteristics of the primary structure of the enzyme. Applied and environmental microbiology. 1993;59:623-7.

140. Sylvestre P, Moya M, Haustant M, Vaissaire J, Mock M. Carbohydrate Metabolism Differences between Subgroup A1 and B2 Strains of Bacillus anthracis as Assessed by Comparative Genomics and Functional Genetics. Applied and environmental microbiology. 2009;75:5727-8.

141. Zajoncova L, Jilek M, Beranova V, Pec P. A biosensor for the determination of amylase activity. Biosensors \& bioelectronics. 2004;20:240-5.

142. Mahosenaho M, Caprio F, L. M, Sesay A, Palleschi G, Virtanen V. A Disposable Biosensor for the Determination of Alpha-amylase in Human Saliva. Microchimica Acta. 2010;170:243-9.

143. Yamaguchi $M$, Deguchi $M$, Wakasugi J. Flat-chip microanalytical enzyme sensor for salivary amylase activity. Biomedical microdevices. 2005;7:295-300.

144. Staden J, Mulaudzi. Flow Injection Spectrophotometric Assay of $\alpha$-amylase Activity. Analytica Chimica Acta. 2000;421:19-25.

145. Wang Q, Wang H, Yang X, Wang K, Liu R, Li Q, et al. A sensitive one-step method for quantitative detection of alpha-amylase in serum and urine using a personal glucose meter. The Analyst. 2014.

146. Shetty V, Zigler C, Robles TF, Elashoff D, Yamaguchi M. Developmental validation of a point-ofcare, salivary alpha-amylase biosensor. Psychoneuroendocrinology. 2011;36:193-9.

147. Ohtomo T, Igarashi S, Takagai Y. Flow injection spectrophotometric analysis of human salivary alpha-amylase activity using an enzyme degradation of starch-iodine complexes in flow channel and its application to human stress testing. Biological \& pharmaceutical bulletin. 2013;36:185761.

148. Wu S, Zhu Y, Cai Q, Zeng K, Grimes C. A wireless magnetoelastic $\alpha$-amylase sensor. Sensors and Actuators B: Chemical. 2007;121:476-81.

149. Attia MS, Zoulghena $\mathrm{H}$, Abdel-Mottaleb MS. A new nano-optical sensor thin film cadmium sulfide doped in sol-gel matrix for assessment of alpha-amylase activity in human saliva. The Analyst. 2014;139:793-800. 
150. Gibbs MJ, Biela A, Krause S. alpha-Amylase sensor based on the degradation of oligosaccharide hydrogel films monitored with a quartz crystal sensor. Biosensors \& bioelectronics. 2014.

151. Sakac N, Sak-Bosnar M, Horvat M, Madunic-Cacic D, Szechenyi A, Kovacs B. A new potentiometric sensor for the determination of alpha-amylase activity. Talanta. 2011;83:160612.

152. Altug C, Mengulluoglu U, Kurt E, Kaya S, Dinckaya E. A novel biosensor based on glucose oxidase for activity determination of alpha - amylase. Artificial cells, blood substitutes, and immobilization biotechnology. 2011;39:298-303. 